Lamia T Rejab

BDS, MSc (Asst. Prof.)

\section{Evaluation of Some Physical Properties of Locally Prepared Alpha-calcium Sulfate Hemihydrate}

\author{
Department of Prosthetic Dentistry
}

College of Dentistry, University of Mosul

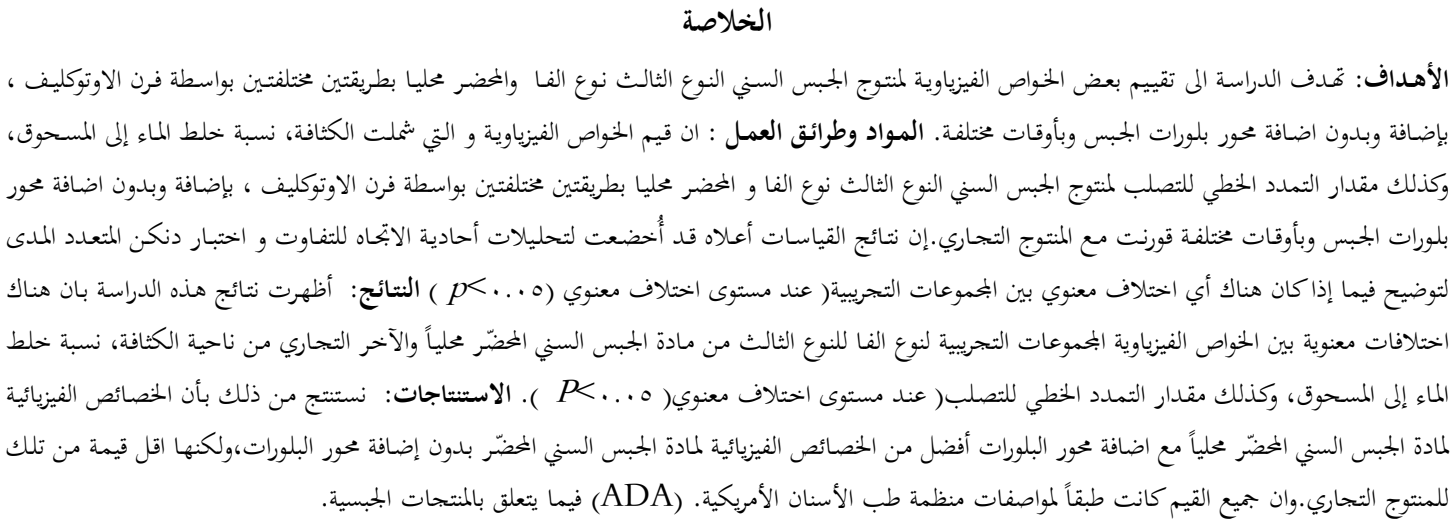

ABSTRACT

Aims: Aim of the study is to evaluate some physical properties of locally prepared dental stone form natural gypsum by two different calcination methods with autoclave with and without adding crystal habit modifier during calcination procedure for different periods of time. Materials and methods: The values of some physical properties that include specific gravity, water/ powder ratio and linear setting expansion of the prepared dental stone with autoclave with and without adding crystal habit modifier during calcination procedure for different periods of time and compared with that of commercial dental stone. ANOVA and Duncan's multiple range test were performed to determine the significant difference among the tested groups at $p \leq 0.05 \%$. Results: Results showed that there were significant differences of the values of the physical properties between the locally prepared dental stone with autoclave and the commercial one at $p \leq 0.05$ in specific gravity, water/ powder ratio and linear setting expansion. Conclusions :The results appeared the alpha- calcium sulfate hemihydrates dental stone that prepared in autoclave with adding crystal habit modifier has superior properties than of that prepared without modifier, but still not reach the properties of the commercial product. All values of the tested properties were in accordance with ADA Specification.

Keywords: Gypsum, Dental stone, Physical properties

Rejab LT. Evaluation of Some Physical Properties of Locally Prepared Alpha-calcium Sulfate Hemihydrate. Al-Rafidain Dent J. 2013; 13(1): 14-20.

Received: 2/6/2011 Sent to Referees: 5/6/2011 Accepted for Publication: 29/6/2011

\section{INTRODUCTION}

The principal constituent of dental stone is calcium sulfate hemihydrates, $\left(\mathrm{CaSO}_{4} \cdot 1 / 2 \mathrm{H}_{2} \mathrm{O}\right)$ as $\alpha$-hemihydrates form. This material is the result of calcining of gypsum(calcium sulfate dehydrate $\left.\mathrm{CaSO}_{4} .2 \mathrm{H}_{2} \mathrm{O}\right)$. Gypsum is ground and subjected to temperature of $\left(110\right.$ to $130^{\circ} \mathrm{C}$ ) to drive off parts of the water of crystallization. $^{(1,2)}$ Several forms of $\alpha$ hemihydrates are available, since the crystals vary with the method of manufacture.
First: dehydration (calcining ) under steam pressure in an autoclave at a temperature of 120 to $150^{\circ} \mathrm{C}$ produce unit crystals of moderate size known as hydrocal. Second: as in first method with organic acids are added to the water, a slightly larger grain size material known as crystacal will produce.Third: by boiling the gypsum in a 30 per cent aqueous solution of $\left(\mathrm{CaCl}_{2}\right)$ the largest crystals are produced which form the basis of densite (improved) stones. ${ }^{(3,4)}$ 
MATERIALS AND METHODS

I: Calcintion of the gypsum: Calcintion of the gypsum(calcium sulfate dihydrate) to produce $\alpha$-calcium sulfate hemihydrates with autoclave oven by two different methods:

Method(1): As in the following steps: 1.Crushing of natural gypsum rock (calcium sulfate dihydrate)that obtained from the same source that the gypsum factoriesin Mosul city and sized to meet the requirements of the calcinations processing by manual way. The gypsum rock is coarsely ground into a grin size of $(150 \mathrm{~mm}$ to $300 \mathrm{~mm})$ in diameter pieces and by using metallic screena certain range of grain size can be selected, so that the finest grain as well as the large lumps size can be eliminated. During calcinations procedure the water suddenly leave the particles as steam producing pressure breaks up the particles into finer crystals. These are then ground further in order to provide variety of particle sizes so necessary to provide a plastic mass when powder is mixed with water. ${ }^{(5,6)}$

2. Elutriation of natural gypsum( purification treatment): Gypsum lumps was elutriated in separate portion in water , the gypsum-water ratio $1: 1(1 \mathrm{~kg}$ gypsum with 1liter water)at elevated temperature between about $60^{\circ} \mathrm{C}$ and $90^{\circ} \mathrm{C}$ for removing organic impurities, the degree of purity of calcium sulfate dihydrate used exerts an extraordinarily large influence upon the recystallization of dihydrate into hemihydrates .The elutriation method removes a large portion of the impurities, both the water soluble and organic constituents, as well as practically all gel-forming impurities. $^{(7)}$

3. Gypsum" lump" pieces with suitable degree of moisture content is fed to an autoclave in the presence of saturated steam for calcination process. Lump pieces are filled into wire baskets and is fed to an autoclave oven (Webelo, West Germany).The autoclave is then closed and the contents heated so as to develop a pressure of from about 1.5 to 2.4 bars pressure gradually which corresponds to a temperature of about from $121{ }^{\circ} \mathrm{C}$ to $135^{\circ} \mathrm{C}$ for five hours time without adding solution of crystal habit modifier. ${ }^{(6)}$ To make, compact prismatic calcium sulfate alpha- hemihydrate crystals one should operate with process temperatures primarily in a range from $120^{\circ}$ to $140^{\circ} \mathrm{C}$.If one operates at processing temperatures of $140^{\circ} \mathrm{C}$ to $160^{\circ} \mathrm{C}$ one obtains an increasing proportion of smaller and heavier crystals of needle-like calcium sulfate anhydride crystals with increasing process temperatures. With temperatures above $160^{\circ} \mathrm{C}$ one obtains a growing proportion of anhydride fragments with longer dwell time. ${ }^{(6,8)}$

4. Drying: At the end of the above operations, the product is quickly dried without allowing it to fall to a temperature at which rehydration would take place (over $45^{\circ} \mathrm{C}$ ). The resulting material was dried in dry oven (Memmert, Germany) for one hour at $150^{\circ} \mathrm{C} .^{(3,6)}$

5. Grinding dried prepared product with grinding machine (Heazog, Germany).Grinding of the particles after preparation of the himehydrate can eliminate needle-like crystals and provide better backing characteristics, hence lowing the amount of mixing or gauging water required. ${ }^{(9)}$

6.Sieving dried prepared product to an appropriate fineness of $98 \%$ through a 100 mesh sieve. ${ }^{(2)}$ The coarse grain dose not lead to rapid strength development, since the reaction per-time unit of coarse grain with water is relatively reduced and incomplete. $^{(9)}$

7.Addition of additives to control the setting time and the setting expansion of the gypsum products, potassium sulfate $\left(\mathrm{K}_{2} \mathrm{SO}_{4}\right)$ in concentration of $2 \%$ was used as an accelerator, whereas the Borax $\left(\mathrm{Na}_{2} \mathrm{~B}_{4} \mathrm{O}_{7} \cdot 10 \mathrm{H}_{2} \mathrm{O}\right)$ in concentrations $1 \%$. was used asa retarder. ${ }^{(10,11)}$

Method (2) : Calcination gypsum " lump" pieces same as in method (1) that mentioned above but gypsum lumps are suspended in a solution of water soluble crystal habit modifier $(0.05 \%$ sodium succinate) and autoclaved for three hours period of time. This followed by washing with boiling water. The $\alpha$-hemihydrate gypsum is introduced rapidly into a drying oven in the baskets and dried. ${ }^{(10,12,13)}$

\section{II: Evaluation of some physical properties of the gypsum products: \\ Some physical properties of locally} prepared $\alpha$-hemihydrates gypsum product 
in the different methods were tested and compared with that of commercial dental stoneas in the following groups:

Group I: control group of the commercial dental stone(Elite dental Stone Zhermack- Italy).

Group II : alpha-hemihydrate gypsum produced in method (1)

Group III: alpha-hemihydrate gypsum produced in method (2)

\section{Measurement of the specific gravi- ty(density) test:}

Specific gravity is a dimensionless unit defined as the ratio of density of the material to the density of water at a specified temperature. ${ }^{(14,15)}$ The method of Hulbut and Klein (1971) ${ }^{(16)}$ of determination of the density was followed by the use of density bottle method asfollowing: ${ }^{(13)}$ tle.

$\mathrm{P}=$ the weight of empty density bot-

$\mathrm{M}=$ the weight of density bottle + gypsum product sample.

$\mathrm{M}-\mathrm{P}=$ weight of gypsum product sample in air.

$\mathrm{S}=$ the weight of density bottle + gypsum product sample + Carbon Tetra chloride $\mathrm{CCl}_{4}$ (The $\mathrm{CCl}_{4}$ is used instead of glycol in this study).

$\mathrm{W}=$ the weight of density bottle $+\mathrm{CCl}_{4}$ alone.

The weight of displaced $\mathrm{CCl}_{4}$ by the gypsum product

$=\mathrm{W}+(\mathrm{M}-\mathrm{P})-\mathrm{S}$

Specific gravity:

$$
\left.\mathrm{CCl}_{4}\right)^{(11)} \mathrm{G}=\frac{(\mathrm{M}-\mathrm{P}) \times 1.56 \text { (specific gravity of }}{\mathrm{W}+(\mathrm{M}-\mathrm{P})-\mathrm{S}}
$$

(M-P) $\times 1.56$ (specific gravity of

Fifteen samples were prepared, five samples for each gypsum products and the mean of these three measurements of each product was calculated.

2. Measurement of the water/powder ratio (Consistency Test):

Modified Vicat Apparatus was used for measuring the water/powder ratio. For measuring the consistency, 300 gm of each type of gypsum products were mixed with of $4 \%$ sodium citrate solution(retarder), poured into the mould and then the top of the mould stroked with spatula. The conical plunger of the device cleaned with a moist tissue before each determination, and lowered to the surface of the sample. The scale is read, and then the plunger released quickly. After the plunger has been settled, the scale is read again. The difference in scale reading is the millimeters of penetration. Determinations are made at 7 , 8 and 9 min. from the start of mixing. Three penetrations were to be averaged for each determination. The average of three determinations ( 9 penetrations) should be taken as a measure for consistency for each of the gypsum products. ${ }^{(17)}$

\section{Measurement of the linear setting expansion measurement:}

The setting expansions of the specimens were measured by modification of the technique described by ADA specification No.25 $(1975)^{(17)}$. The device consisted of rectangular metal box having the dimension of $104 \mathrm{~mm}$ in length and $58 \mathrm{~mm}$ in width with one fixed end stop and one movable brass slide. The motion of the free brass end was monitored by a dial gauge against the brass slide movement of the free brass end was monitored by a dial gauge. One hundred gram of each sample mixed with distilled water according to a previously determined water/ powder ratio(the test is perform 5 times for each gypsum products. The mold should be lined with separating media like Vaseline, prior to pour the mixture. The dial gauge was adjusted (by placing the pointer on zero); the change of specimen length on setting was determined by observing the movement of the dial gauge. The initial reading (IR) was taken one minute prior to the measuring setting time and the final reading (FR) was taken two hours after mixing. Measured by using digital vernia in millimeter. The setting expansion was calculated according to the following formula: (Al-Ameer, 2002): ${ }^{(18)}$

$$
\Delta \mathrm{L} \%=\mathrm{FR}-\mathrm{IR} / \mathrm{L} \times 100
$$

$\Delta \mathrm{L} \%=$ Percentage of setting expansion.

$\mathrm{L}=$ Actual length of the specimen

Fifteen samples were prepared. Five samples to each group.

Statistical Analysis:One-way analysis of variance (ANOVA) and Duncan's multiple range test were performed to determine the significant difference among the tested groups at $p \leq 0.05 \%$. 


\section{RESULTS}

The result in Table (1) shows meanand standard deviation of the spesific gravity of the tested gypsum groups. The result appeared that the mean of the specific gravity of the GroupI (control commercial stone) was $\left(2.62 \mathrm{gm} / \mathrm{cm}^{3}\right)$, for GroupII $\left(2.51 \mathrm{gm} / \mathrm{cm}^{3}\right)$ andfor GroupIII $\left(2.60 \mathrm{gm} / \mathrm{cm}^{3}\right)$.The specific gravity of the pure natural (calcium sulfate dihydrate) is $\left(2.32 \mathrm{gm} / \mathrm{cm}^{3}\right)$ and for (calcium sulfate hemihydrate) is $\left(2.75 \mathrm{gm} / \mathrm{cm}^{3}\right){ }^{(9)}$ All values of the testedgroup is higher than that of thecalcium sulfate dihydrate, that means that the natural gypsum when heated with autoclave in Group II and GroupIII drive off part of the water of crystallization and converted into calcium sulfate hemihydratewhich has high bullk density (specific gravity). ${ }^{(9)}$ So specific gravity give an indication of conversion, and it is such a useful property that it is the only way to distinguish some minerals without laboratory or optical techniques. So there are quite significant differences observed between the apparent densities of different gypsum products. ${ }^{(19)}$

Table(1): Mean and standard deviation of the specific gravity of the tested gypsum groups

\begin{tabular}{cccc}
\hline Group & No & Mean $\left(\mathbf{g m} / \mathbf{c m}^{\mathbf{3})}\right.$ & $\mathbf{\pm}$ Standard deviation \\
\hline Group I & 5 & 2.62 & 0.0158 \\
Group II & 5 & 2.51 & 0.0114 \\
Group III & 5 & 2.60 & 0.0158
\end{tabular}

Group I:controlGroup II: gypsum produced without modifier, Group II: gypsum produced with modifier No: number of samples

The result in Tables (2-3) show ANOVA and Duncan's multiple range test of means of the specific gravity of the tested gypsum groups. The result shows thereis a significant difference between tested groups of gypsum product.Gypsum product in Group II that calcinated in autoclave without crystal modifier agent and longer period of time (5 hours) has the lowest value than that of the other tested groups, this means it has less degree of recrystallization transformation (conversion )than other groups . This could be explained in that,the gypsum to be calcined depend on particle size, and length of calcinations, process for making the alphahemihydrate gypsum from natural gypsum structures arise with diffuse crystal structures in the core of the individual pieces of the gypsum stone and the recrystallization transformation dose not occur satisfactorily,${ }^{(9)}$ so large gypsum pieces (lump) need more time of calcination to get higher degree of conversion. While gypsum product in Group III when calcinated in autoclave with water soluble crystal modifier agent $(0.05 \%$ sodium succinate) and with shorter time (3hours) has higher value of specific gravity than that of Group II . This could be explained in that in order to accelerate this reaction, the usual accelerating agents can be used, gypsum is suspended in a solution of crystal habit modifier and autoclaved. Properties further enhanced by cooking in solution containing from about $0.05 \%$ of succinic acid or a water-soluble succinic acid salt. ${ }^{(13)}$

Table (2): ANOVA of means of the specific gravity of the tested gypsum groups

\begin{tabular}{cccccc}
\hline & Sum of square & df & Mean square & F-value & $\boldsymbol{p}$ \\
\hline Between groups & 0.032 & 2 & 0.016 & 75.524 & 0.000 \\
Within groups & 0.003 & 12 & 0.000 & & \\
Total & 0.034 & 14 & & & \\
\hline
\end{tabular}

Means significant difference at $p \leq 0.05 \%$ 
Table (3) : Duncan's multiple range test for the means of the specific gravity of the tested gypsum groups

\begin{tabular}{cccc}
\hline Group & No & Mean $\left(\mathbf{g m} / \mathbf{c m}^{\mathbf{3}}\right)$ & Duncan grouping * \\
\hline Group I & 5 & 2.51 & $\mathrm{~A}$ \\
Group II & 5 & 2.60 & $\mathrm{~B}$ \\
Group III & 5 & 2.62 & $\mathrm{C}$ \\
\hline
\end{tabular}

*Means with different letters are significantly different

The result in Table (3) also shows that commercial stone has the highest value of the specific gravity than other tested groups, This explained in that the commercial stone contains extra salts to control the properties of the stone .It is one of the manufacturer secrets. ${ }^{(2)}$

The result in Table (4) shows the mean and standard deviation of the water/powder ratio of the tested gypsum groups. The result appeared that the Group I has water/ powder ratio (31.8 $\mathrm{ml} / \mathrm{gm})$,Group II has w/p ratio (36.3 $\mathrm{ml} / \mathrm{gm})$, and Group III has w/p ratio (33.2 $\mathrm{ml} / \mathrm{gm})$. The result appeared that values of $\mathrm{w} / \mathrm{p}$ ratio for all tested groups are accordance with ADA Specification No.25.This result give indication that the resultant material in Group II and Group III is calcium sulfate hemihydrates of alpha form not beta form. Since a practical method of distinguishing the two forms has been to use the amount of water required to make a flowable paste from $100 \mathrm{gm}$ of a hemihydrates. The alpha form has a low water demand of $(30-40 \mathrm{ml})$, while the beta form relatively higher demand of (40-50 $\mathrm{ml}){ }^{(17,20)}$

Table (4): Mean and standard deviation of the water/powder ratio of the tested gypsum groups

\begin{tabular}{cccc}
\hline Group & No & Mean(ml/100g) & 土 Standard deviation \\
\hline Group I & 5 & 31.8 & 0.1511 \\
Group II & 5 & 36.3 & 0.3962 \\
Group III & 5 & 33.2 & 0.1140 \\
\hline
\end{tabular}

Group I:controlGroup II: gypsum produced without modifier ,Group II: gypsum produced with modifier No: number of samples

The result in Tables (5-6) show ANOVA and Duncan's multiple range test of means of the w/p ratio of the tested gypsum groups. The result shows thereis a significant difference between tested groups of gypsum product. This difference is related to the difference in the specific gravity of the tested gypsum products as shown in Table (2). The significant difference in the value of the water/powder ratio depend on specific gravity of the particles. ${ }^{(15,21)}$ The result shows that the $\mathrm{w} / \mathrm{p}$ ratio of gypsum product in Group III is significantly less than that of Group II. This can be explained in that the alpha-calcium sulfate hemihydrate resultant in Group III with crystal habit modifier would has relatively large crystal size. Since practically when crystal habit modifier to be used large crystal would be made and the large crystals with less surface area dose not have high water requirement. ${ }^{(9)}$ This result supported by Anderson. ${ }^{(3)}$

Table(5): ANOVA of means of the water/ powder ratio of the tested gypsum groups

\begin{tabular}{cccccc}
\hline & Sum of square & df & Mean square & F-value & $p$ \\
\hline Between groups & 2 & 26.659 & 410.133 & 0.000 \\
Within groups & 12 & 0.065 & & \\
Total & 14 & & & \\
\hline
\end{tabular}

Means significant difference at $p \leq 0.05 \%$ 
Table(6): Duncan's multiple range test means of the water/ powder ratio of the tested gypsum

\begin{tabular}{cccc}
\multicolumn{3}{c}{ groups } \\
\hline Group & No & Mean $(\mathbf{m l} / \mathbf{1 0 0 g})$ & Duncan grouping* \\
\hline Group I & 5 & 31.8 & $\mathrm{~A}$ \\
Group II & 5 & 36.3 & $\mathrm{~B}$ \\
Group III & 5 & 33.2 & $\mathrm{C}$ \\
\hline
\end{tabular}

*Means with different letters are significantly different at $p \leq 0.05 \%$

The result in Table (7) shows meanand standard deviation of the linear setting expansion of the tested gypsum groups. The result shows thatmean of the linear setting expansion of the GroupI was $(0.07 \%)$,for GroupII $(0.17 \%)$ andfor GroupIII $(0.11 \%)$. All values for tested groups are accordance with ADA Specifi- cation No.25.The expansion result from the thrusting action of the gypsum crystals (calcium sulfate dihydrate) during their growth from supersaturated solution according to the crystalline theory. ${ }^{(1)}$ This result supported with the result of William etal. and others. ${ }^{(22,23)}$

Table (7): Mean and standard deviation of the linear setting expansion of the tested gypsum groups

\begin{tabular}{cccc}
\hline Group & No & Mean ( \%) & 土 Standard deviation \\
\hline Group I & 5 & 0.07 & 0.0114 \\
Group II & 5 & 0.17 & 0.0114 \\
Group III & 5 & 0.11 & 0.0114 \\
\hline
\end{tabular}

Group I:control Group II: gypsum produced without modifier, Group II: gypsum produced with modifier No: number of samples

The result in Tables (8-9) show ANOVAand Duncan's multiple range test of means of the linear setting expansion of the tested gypsum groups. The result shows thereis a significant difference between tesred groups of gypsum product. The result showed the linear setting expansion value of the gypsum product in Group III is significantly less than that of Group IIbut significantly higher than that of Group I. This is related to the differences in the $w / p$ ratio of the different tested groupsas shown in Table (6). The less $\mathrm{w} / \mathrm{p}$ ratio the greater is the setting expansion, since with higher w/p ratio, fewer nuclei of crystallization per unit volume are present than with the thicker mix, and the space between the nuclei will be greater, it follows that there will be less growth interaction of the dehydrate crystals with less outward thrust resulting. ${ }^{(9)}$

Table(8): ANOVA of means of the linear setting expansion of the tested gypsum groups

\begin{tabular}{cccccc}
\hline & Sum of square & df & Mean square & F-value & $\boldsymbol{p}$ \\
\hline Between groups & 2 & 0.013 & 97.436 & 0.000 \\
Within groups & 12 & 0.000 & & \\
Total & 14 & & & \\
\hline
\end{tabular}

Means significant difference at $p \leq 0.05 \%$

Table (9): Duncan's multiple range test means of the linear setting expansion of the tested

\begin{tabular}{cccc}
\multicolumn{3}{c}{ gypsum groups } \\
\hline Group & No & Mean( \%) & Duncan grouping* \\
\hline Group I & 5 & 0.07 & $\mathrm{~A}$ \\
Group II & 5 & 0.17 & $\mathrm{~B}$ \\
Group III & 5 & 0.11 & $\mathrm{C}$ \\
\hline
\end{tabular}

*Means with different letters are significantly different at $p \leq 0.05 \%$ 


\section{CONCLUSIONS}

The results appeared there is a significant difference of the values of the physical properties ( specific gravity, water/ powder ratio and linear setting expansion) between the control commercial alpha- calcium sulfate hemihydrates dental stone, and that prepared in autoclave with and without adding crystal habit modifier. Alpha- calcium sulfate hemihydrates prepared with modifier has superior properties but still not reach the properties of the commercial product. All values of the tested properties were in accordance with ADA Specification.

\section{REFERENCES}

1. Anusavice KJ.Phillips science of dental materials $11^{\text {th }}$ ed.Philadelphia:Elsevier science USA. 2003; p.255-281.

2. Graig RG, Hanks CT, Kohn DH, O'Brien WJ, Powers JM, Wagner WC, Wataha JC. Restorative dental materials. $10^{\text {th }}$ ed, Mosby Co. Missouri, USA. 1997; pp: 333-360.

3. Anderson JN .Applied dental materials. $4^{\text {th }}$ ed. Blackwell Scientific publication. London UK.1972; chap.20, pp.157-169.

4. Graig RG, powers JM, Wataha JC. Dental Materials Properties and manipulation. $8^{\text {th }}$ ed, Mosby Company, USA. 2004; pp: 204, 208.

5. Philips RW. Element of dental materials. $4^{\text {th }}$ ed. W.B.Saunder Co. Philadephia, USA.1984;pp:52-72.

6. Manvel CD, Palo A and Elmer S. Process for production of high strength low consistency calcined gypsum. US Patent 2,913,308;(1959).

7. Hermann R and Ludwigshafen R. Production of alpha-calcium sulfate hemihydrates.US Patent 3,410,655.(1968)

8. Koslowski and Thomad J. Process for calcium sulfate alpha-hemihydrate from calcium sulfate dihydrate. US Patent 5015450. (1991).

9. Phillip RW. Skinner's Science of dental materials $8^{\text {th }}$ ed.W.B.Saunder Co. Philadephia, USA.1982; pp:63-89

10. Graig RG, O’Brien WJ, powers JM. Dental Materials Properties and Manipulation. $6^{\text {th }}$ ed. Mosby Co. Missouri, USA.1996; pp: 183-213.
11. Farouk S. Evaluation of some physical properties of die stone made from local raw gypsum material. MSc. Thesis, University of Mosul.2009.

12. Frame JW. Porous calcium sulphate dehydrate as a biodegradable implant in bone. J Dent.1974;(3)4:177-187.

13. Comb EC. Notes on dental materials. $5^{\text {th }}$ ed. Chrchill Livingstone. London, UK. 1986; PP:299-311.

14. Mohammed SA. The effect of processing variable on the surface hardness, flow and setting time of gypsum materials. MSc. Thesis, University of Alabama.1983.

15. Schelb E, Cavazos E, Kaiser DA, Troendle K. Compatibility of type IV dental stones with polyether impression materials. J Prosthet Dent.1988; 60(5): 540-542.

16. Hulbut CS and Klein C. Mannual of mineralogy(after James Dana). $19^{\text {th }}$ ed. 1971;Wiley, New York.USA P.532.

17. American Dental Association Specification. Guide to dental materials and devices. $7^{\text {th }}$ ed.1974-1975; pp: 86-96, 255-260.

18. Al-Ameer SS, and Berko RY. Effect of madacide disinfectant solution on some of the physical and mechanical properties of dental stone. Iraqi Dent J.2002; 29:219-244.

19. Comb EC and Smith DC. Some properties of the gypsum materials .Brit. Dent .J.1964; 117:237.

20. Donald WK. Process for the production of alpha hemihydrates calcium sulfate from flue gas sludge.US Patent 1996.5,562,892.

21. Graig RG and Power JM. Restorative dental materials $.11^{\text {th }}$ edMosby Co.Missouri, USA .2002;pp 635670,392-404.

22. William WN, Carl GW and Virender BD. Delayed linear expansion of improved dental stone. $J$ Prosthet Dent.2002;(88)1:26-31

23. Michalakis KX, Stratos A and Hirayama H. Delayed setting and hygroscopic expansion of three gypsum products used for cast articulation. Prosthet Dent.2009; (102)5:26-31. 